Obere Extremität 2020 · 15:28-34 https://doi.org/10.1007/s11678-020-00558-0 Received: 6 December 2019

Accepted: 15 January 2020

Published online: 8 February 2020

(c) The Author(s) 2020

Philipp A. Michel ${ }^{1}$ (D) - Benedikt Schliemann' - Michael J. Raschke'

J. Christoph Katthagen' ${ }^{1}$ Lukas F. Heilmann' · Felix Dyrna' · Florian Sax ${ }^{2}$. Mara Warnhoff ${ }^{2} \cdot$ Helmut Lill ${ }^{2} \cdot$ Rony-Orijit Dey Hazra ${ }^{2}$

' Department of Trauma, Hand and Reconstructive Surgery, University Hospital Münster, Münster, Germany

${ }^{2}$ Department of Orthopedics and Traumatology, DIAKOVERE Friederikenstift, Hannover, Germany

\title{
Outcome after operative revision of clavicular nonunions
}

\section{Clinical and radiographic results}

Fractures of the clavicle are common and account for around $3 \%$ of all adult fractures [5]. The incidence ranges from 64 to $71 / 100,000$ per year $[10,23]$. Historically, midshaft clavicular fractures have been treated nonoperatively with good functional outcomes. A major complication of conservative therapy is the relatively high nonunion rate, which is reported to be $15-20 \%$ in some studies [32, 33].

In the past decade, randomized control trials have been conducted to compare operative and nonoperative therapy of midshaft clavicular fractures. A recent meta-study concludes that surgical treatment significantly reduces the nonunion rate, shortens the time to union, and, despite a slightly higher incidence of complications, leads to better shoulder functional scores in both short- and longterm follow-up [9]. Although other studies state that there is still no consensus on treatment, there has been an overall paradigm shift towards operative therapy with open reduction and plate fixation $[18,27,29]$. However, the problem of

\begin{tabular}{ll}
$\begin{array}{l}\text { Table } 1 \\
\text { hort }\end{array}$ & Epidemiological data of the co- \\
\hline Total patients & $\boldsymbol{n}=\mathbf{3 1}$ \\
\hline Age (years) & $\begin{array}{l}52.3 \pm 15.2 \text { (range: } \\
32-84)\end{array}$ \\
\hline Male vs. female & $\begin{array}{l}12(38.7 \%) \text { vs. } 19 \\
(61.3 \%)\end{array}$ \\
\hline $\begin{array}{l}\text { Body weight (kg) } \\
80.4 \pm 22.1 \text { (range: } \\
51-160)\end{array}$ \\
$\begin{array}{l}\text { Right- vs. left- } \\
\text { handed }\end{array}$ & $29(93.5 \%)$ vs. $2(6.5 \%)$ \\
\hline
\end{tabular}

nonunion remains after both conservative and operative management.

Less is known about the results after revision of clavicular nonunions, regardless of whether the initial therapy was operative or nonoperative. Nonunion is either atrophic or hypertrophic. Most studies report a higher rate of atrophic nonunions (see $\bullet$ Table 5). The surgical procedure usually includes a resection of the nonunion (decortication according to Judet) and (angular stable) plating combined with autologous bone grafting [20, 28]. Bony union can reliably be achieved with this technique $[6,25]$. McKnight et al. compared the surgical management of midshaft clavicular nonunions with that of acute fractures and found an increased risk of short-term complications such as wound infections [21]. Long-term results are scarce. O'Conner et al. found a higher level of disability according to assessment with the Disabilities of Arm, Shoulder, and Hand (DASH) questionnaire in the operated group com- pared with the normal population after a mean follow-up of 42.1 months [24].

The aim of the present study was therefore to examine the clinical and radiographic results after operative revision of clavicular nonunions in a multicenter study. We hypothesized that the functional results would be similar to the noninjured side and that radiographic fracture union could be achieved in the majority of the cases.

\section{Methods}

\section{Study design and patient cohort}

Two level-1 trauma centers in northwestern Germany conducted a retrospective analysis of patients with clavicular nonunion who needed revision surgery during the past 10 years. The study was approved by the local ethics committees (2019-159-f-S/8688_BO_S_2019). All patients who underwent operative revision for clavicular nonunion in these two hospitals were included. Patients
Table 2 Mean values of active range of motion

\begin{tabular}{|c|c|c|c|}
\hline Movement & Injured side & Noninjured side & $p$ \\
\hline Anteversion & $162 \pm 22^{\circ}$ & $170 \pm 4^{\circ}$ & 0.0953 (ns) \\
\hline Retroversion & $39 \pm 5^{\circ}$ & $40 \pm 4^{\circ}$ & 0.9993 (ns) \\
\hline Abduction & $163 \pm 30^{\circ}$ & $174 \pm 10^{\circ}$ & $\left.0.00644^{(*}\right)$ \\
\hline Adduction & $37 \pm 8^{\circ}$ & $39 \pm 7^{\circ}$ & 0.9746 (ns) \\
\hline External rotation ${ }^{\mathrm{a}}$ & $83 \pm 13^{\circ}$ & $85 \pm 8^{\circ}$ & 0.9692 (ns) \\
\hline Internal rotation ${ }^{\mathrm{a}}$ & $73 \pm 11^{\circ}$ & $75 \pm 9^{\circ}$ & 0.9939 (ns) \\
\hline \multicolumn{4}{|c|}{$\begin{array}{l}\text { ns Nonsignificant, }{ }^{* *} \text { significant } \\
\text { In } 90^{\circ} \text { abduction }\end{array}$} \\
\hline
\end{tabular}



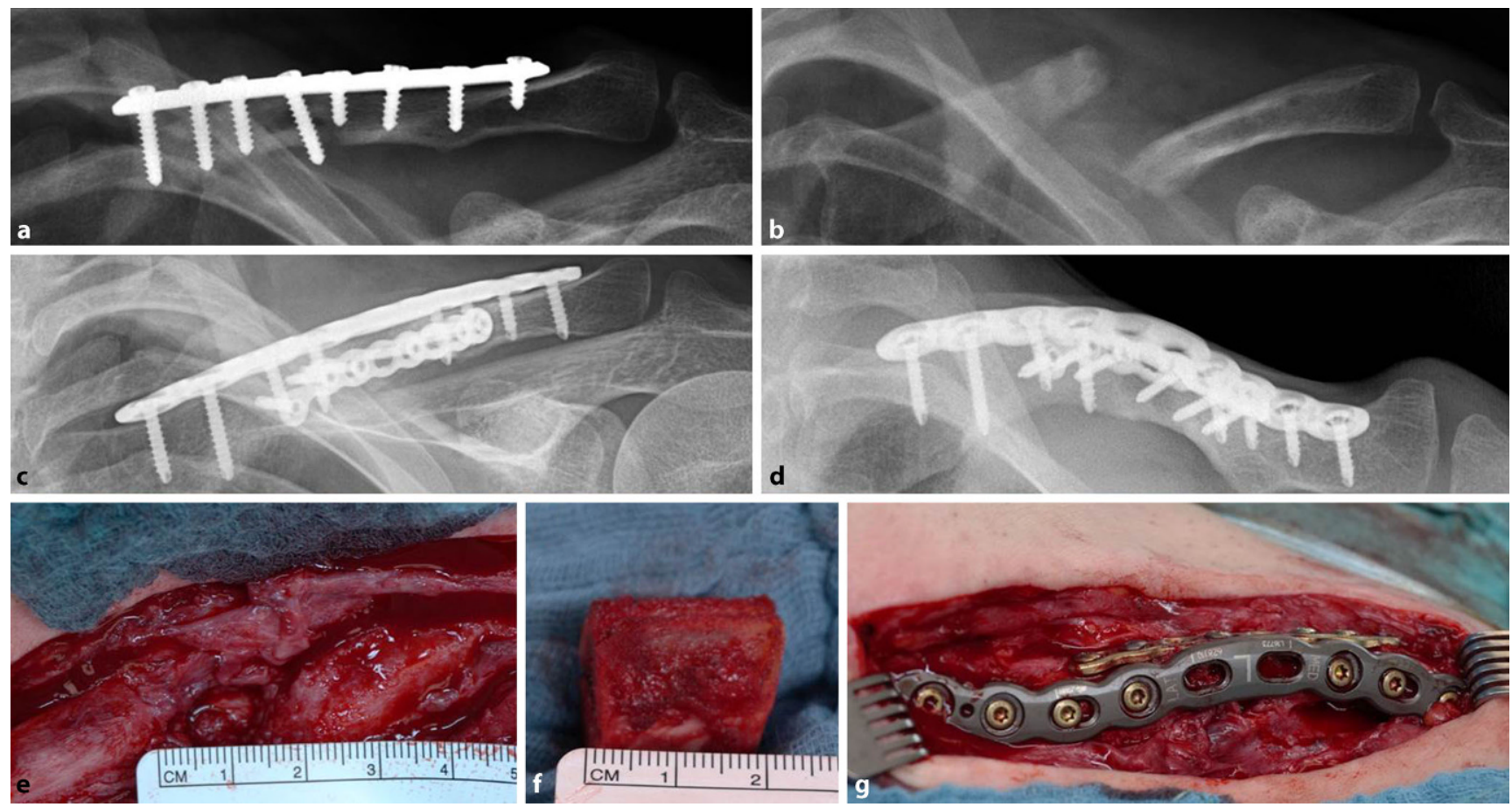

Fig. $1 \Delta$ Case of a 35-year-old male patient who had a mountain bike accident. Presentation 6 months after trauma to our department with two previous operations after medial implant loosening (a).Complete removal of the material was necessary after verification of a septic nonunion (b). After antibiotic therapy, surgical revision was performed (c). Intraoperatively, a 2-cm bony defect was seen (e). Accordingly, an autologous bone graft from the iliac crest (f) was combined with double plating (g). $\mathrm{X}$-rays 1 year postoperatively show complete union of the defect $(\mathrm{d})$

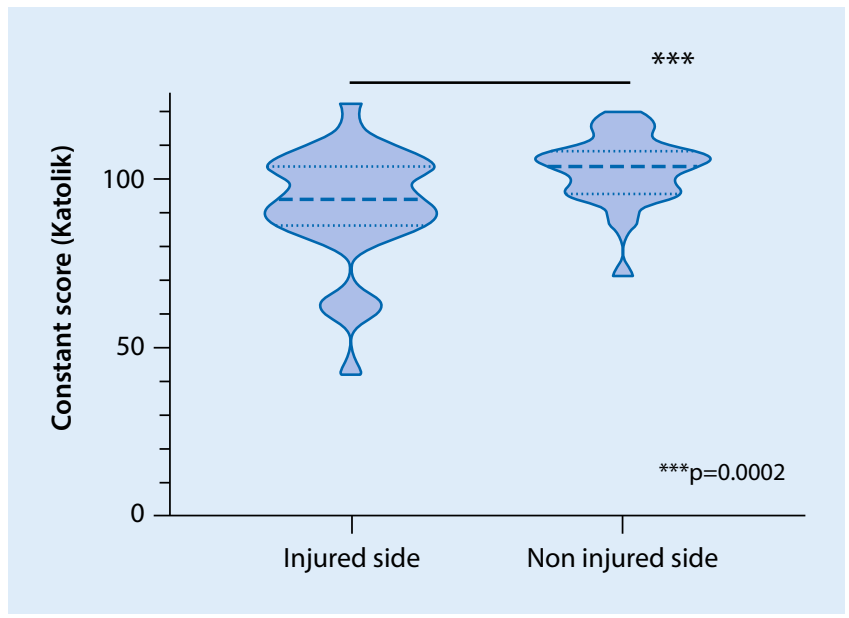

Fig. $2<$ Age-and gender-adjusted Constant score according to Katolik for the injured and noninjured shoulder

with a record of pre-existing shoulder conditions (e.g., osteoarthritis), earlier operations at the injured side, or regular immunosuppressive medication were excluded. This was a two-center retrospective cohort study with a level III of evidence.

\section{Outcome assessment}

All patients underwent a structured clinical and radiological assessment. The clinical interview included a survey of the relevant epidemiological data, preexisting illness, and individual course of treatment. Risk factors such as smoking, diabetes, and osteoporosis (when explicitly stated as a diagnosis in the patient reports) were also recorded. Pain was assessed using the Visual Analog Scale (VAS). The major outcome parameter was functional assessment using the age- and gender-adjusted Constant score according to Katolik [14].
For the radiographic follow-up, the major outcome parameter was fracture union on conventional X-rays of the clavicular in two planes (anteroposterior [ap] and tangential). This was defined by three continuous cortices. Technical aspects, such as the plate type and length as well as usage of conventional and angular stable screws, were also recorded. Furthermore, the usage of autologous bone grafting was noted. This was harvested either from the iliac crest or from the resected hypertrophic nonunion itself (decorticated bone was cleaned from soft tissue, reduced to small chips, and used for bone grafting). Additionally, complications such as wound site infections with re-operation and the occurrence of paresthesia were examined.

\section{Statistical analysis}

Data were collected in a Microsoft Excel data sheet. Mean and standard deviations were calculated where applicable. Statistical analysis was performed with GraphPad (GraphPad Prism 8.3.0, San Diego, CA, USA). Welch's $t$ test and two- 
Obere Extremität 2020 · 15:28-34 https://doi.org/10.1007/s11678-020-00558-0

(c) The Author(s) 2020

P. A. Michel · B. Schliemann · M. J. Raschke · J. C. Katthagen · L. F. Heilmann · F. Dyrna · F. Sax · M. Warnhoff · H. Lill · R.-O. Dey Hazra Outcome after operative revision of clavicular nonunions. Clinical and radiographic results

\section{Abstract}

Background. Over the past decade, the treatment of midshaft clavicular fractures has increasingly shifted from conservative to operative therapy. The overall results seem to be better with surgery, although the problem of nonunion remains. The aim of this study was to report the functional results after operative revision of clavicular nonunions in two German level-1 trauma centers.

Methods. All patients who underwent surgery for clavicular nonunions during the past 10 years were invited for a structured clinical follow-up examination. The major functional outcome parameter was the age- and gender-adjusted Constant score. Additionally, radiographic fracture union was assessed with the available $X$-rays. Complications such as wound site infections were also monitored. Results. In total, 31 patients were available for assessment. The mean follow-up rate was $69.7 \pm 31.2$ months. The mean age of the patients was $52.3 \pm 15.2$ years. The nonunion was classified as atrophic in 26 cases and hypertrophic in five. A total of 25 $(80.6 \%)$ patients were treated with angular stable plating combined with autologous bone grafting from the iliac crest. The ageand gender-adjusted Constant score was significantly decreased compared with the noninjured side ( $82.2 \pm 17.1$ vs. $95.6 \pm 10)$. Radiographic union was achieved in 30 of the 31 patients $(96.8 \%)$. Complications with need for surgical revision were recorded for two patients.

Conclusion. Surgery for clavicular nonunion is a safe and well-established procedure, which leads to radiographic union and good functional results for the majority of cases.

Keywords

Clavicle $\cdot$ Clavicle fracture $\cdot$ Constant score Revision surgery · Radiographic union

\section{Ergebnisse nach operativer Revision von Klavikulapseudarthrosen. Klinische und radiologische Befunde}

\section{Zusammenfassung}

Hintergrund. Die Behandlung von Klavikulaschaftfrakturen hat sich aufgrund der Studienergebnisse der letzten Jahre zunehmend von der konservativen zur operativen Therapie gewandelt. Eine der Hauptkomplikationen bleibt jedoch weiterhin die Pseudarthrose. Das Ziel dieser Studie war es, funktionelle Ergebnisse nach operativer Revision in 2 Level-1-Traumazentren zu untersuchen.

Material und Methoden. Es wurden alle Patienten zu einer Nachuntersuchung eingeladen, die in einem Zeitraum von 10 Jahren an den beiden Kliniken mit einer Klavikulapseudarthrose operativ behandelt wurden. Der Hauptparameter für das funktionelle Outcome war der modifizierte
Constant-Score. Zusätzlich wurde anhand der verfügbaren Röntgenbilder die knöcherne Konsolidierung erfasst. Komplikationen wie Wundinfektionen wurde ebenfalls dokumentiert.

Ergebnisse. Es konnten 31 Patienten nachuntersucht werden. Das durchschnittliche Follow-up war 69,7 $\pm 31,2$ Monate. Das durchschnittliche Patientenalter lag bei $52,3 \pm 15,2$ Jahren. Die Pseudarthrose wurde in 26 Fällen als atroph und in 5 Fällen als hypertroph klassifiziert. Bei 25 Patienten $(80,6 \%)$ erfolgte eine autologe Spongiosaplastik vom Beckenkamm mit winkelstabiler Plattenosteosynthese. Der alters- und geschlechtsadjustierte Constant-Score war signifikant geringer als auf der gesunden
Gegenseite $(82,2 \pm 17,1$ vs. $95,6 \pm 10)$. Eine Konsolidierung im Röntgenbild wurde in 30 von 31 Fällen festgestellt. Revisionspflichtige Komplikationen zeigten sich in 2 Fällen.

Schlussfolgerung. Die operative Therapie einer Klavikulapseudarthrose ist ein sicheres und etabliertes Verfahren, welches gute Konsolidierungsraten zeigt und in den meisten Fällen zu guten funktionellen Ergebnissen führt.

\section{Schlüsselwörter}

Klavikula · Klavikula-Fraktur · Constant Score $\cdot$ Revisionschirurgie $\cdot$ Radiologische Konsolidierung way ANOVA were used with Sidak's multiple comparisons test and significance was set at $p<0.05$.

\section{Results}

A total of 31 patients from the two centers were available for follow-up. No patients had to be excluded because of the exclusion criteria defined earlier.

\section{Epidemiological data}

The data of 31 patients were analyzed for this study. General epidemiologic data of the cohort are summarized in $\bullet$ Table 1.

\section{Initial treatment}

The etiology was a mono-trauma of the clavicle in $28(90.3 \%)$ patients, and only three $(9.7 \%)$ patients suffered a polytrauma. In $18(58.1 \%)$ patients the left side was injured; 14 of the 31 (45.1\%) patients were treated in a primarily conservative manner, of whom four (28.6\%) had to undergo surgery later than 42 days after trauma owing to secondary dislocation. For 17 patients, surgery was performed primarily within $6.6 \pm 8.2$ days (range: $0-35$ ). The mean operation time was $53.3 \pm 15.8 \mathrm{~min}$ (range: $37-80$ ) but these data were only available for six of the operated patients. In summary, ten $(32.6 \%)$ patients were treated conservatively prior to revision surgery while $21(67.7 \%)$ patients underwent primary surgery or conversion to surgery. In seven (33.3\%) surgically treated patients an angular stable plate was used, while an elastic stable intramedullary nail (ESIN) was 


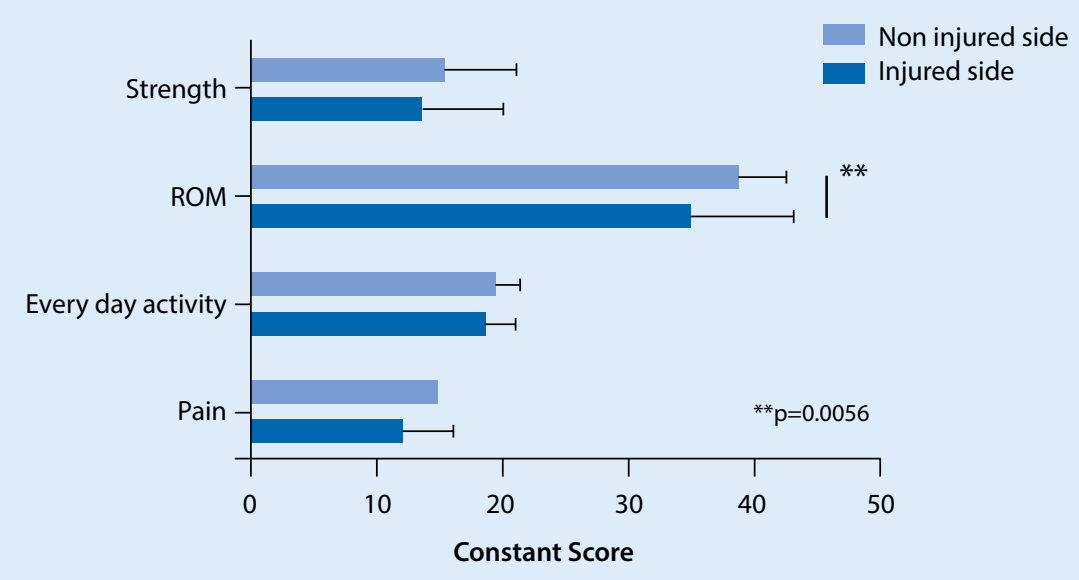

Fig. 3 The different outcome categories for the Constant score. ROM range of motion

inserted in three (13\%) patients (no information on fixation material in 11 patients, 52.4\%). The mean plate length was $7.6 \pm 2.3$ holes (range: 6-10).

\section{Revision surgery}

Data on revision surgery were available for all 31 patients. The mean time from trauma to revision was $19.9 \pm 20$ months (range: 4-107). The nonunion was classified as atrophic in $26(83.9 \%)$ patients and hypertrophic in five (16.1\%) patients. The mean radiographic distance of the nonunion gap was $10.9 \pm 6.6 \mathrm{~mm}$. A loss of reduction in the operated cohort was noted in $16(76.2 \%)$ cases while an implant breakage was present in five (23.8\%) patients. The number of previously conducted operations prior to the revision surgery in one of the two hospitals ranged from 1 to 3 with a mean of $1.38 \pm 0.59$ operations per patient. In nine (42.9\%) cases the implants were already removed.

The mean operating time of the revision was $96.3 \pm 35.9 \mathrm{~min}$ (range: $49-174$ ). A straight angular stable plate was used in 19 cases $(61.3 \%)$, while a pre-contoured plate was utilized in $8(25.8 \%)$ cases. The mean plate length was $8.7 \pm 1.4$ holes with an average of $7.5 \pm 1.2$ screws per plate $(4.3 \pm 2.5$ conventional screws $/ 3.2 \pm 3$ locking screws). In 25 (80.6\%) patients, autologous bone grafting was used, either from the iliac crest (54.8\%) or from the resected nonunion (25.8\%). Representative $\mathrm{X}$-rays and intraoperative images from a study patient are shown in • Fig. 1.

\section{Clinical outcome}

The clinical survey and assessment were conducted with a mean follow-up of $69.7 \pm 31.2$ months. Eight $(25.8 \%)$ of the patients reported active smoking, while $17(54.8 \%)$ stated no pre-existing illnesses. None of the patients had a history of osteoporosis or diabetes. The active range of motion is summarized in - Table 2. In total, 29 (93.5\%) patients could return to their previous work and $28(90.3 \%)$ could return to sport. A total of $26(83.9 \%)$ patients were able to conduct overhead work after revision surgery. Moreover, 27 (87.1\%) of the patients answered the question: "Were you satisfied with revision surgery?" with "Yes" and the same number of patients would opt for revision surgery again.

Pain at rest measured with the VAS for the injured side was $0.5 \pm 1.5$ (range: $0-7$ ) while stress-induced pain was $1.7 \pm 2.7$ (range: 0-8). Eight (25.8\%) patients had tenderness on palpation, three $(9.7 \%)$ patients reported taking regular pain medication, and five $(16.1 \%)$ patients regularly received physiotherapy. Two patients had to be re-operated because of a postoperative complication (infection), yielding a complication rate of $6.5 \%$ : one patient was from the primarily conservative and the other from the primarily operated group. At the time of followup, $19(61.3 \%)$ patients had their implants removed. A total of 20 (64.5\%) patients reported paresthesia above or ventral of the clavicle. The total number of operations for all patients was $2.54 \pm 0.87$ (range: 1-4).

\section{Constant score}

The analysis of the age-adjusted Constant score according to Katolik et al. [14] showed a difference between the injured and noninjured side (• Fig. 2). The breakdown of the different categories within the Constant score revealed a significant difference in the range of motion. The other categories also showed a tendency toward lower scores for the injured side, although these differences were not significant (• Fig. 3).

\section{Radiological outcome}

The mean radiological follow-up after revision surgery was $49 \pm 30$ months (range: $2-120)$. Fracture union was seen in 30 (96.8\%) patients while no implant breakage, loosening, or loss of reposition were detected. Ossifications were present in 23 (74.2\%) patients.

\section{Initial treatment: nonoperative vs. operative}

A total of ten patients underwent nonoperative treatment, while 21 were operated on (initial treatment before revision surgery). We compared these groups in terms of the major outcome criteria. Epidemiological data are summarized in - Table 3. The conservative group included significantly more smokers.

The main clinical and functional outcome parameters are summarized in - Table 4. Apart from the number of operations, no significant differences were detected. There were also no differences in all of the other aforementioned parameters (data not shown).

\section{Discussion}

The most important finding of our study is that revision surgery of clavicular nonunions can lead to satisfying midterm functional outcomes. The great majority of patients were satisfied with 
Table 3 Epidemiological data of conservative vs. operative treatment groups (initial treatment before revision surgery)

\begin{tabular}{|c|c|c|c|}
\hline & Conservative & Operative & $p$ \\
\hline Total patients & $n=10$ & $n=21$ & - \\
\hline Male & 5 & 14 & $0.3732^{\mathrm{a}}$ \\
\hline Female & 5 & 7 & \\
\hline Smoker & 5 & 3 & $0.0336^{\mathrm{a}}$ \\
\hline Age (years) & $57 \pm 15.4$ & $50 \pm 14.2$ & $0.2423^{b}$ \\
\hline Body weight $(\mathrm{kg})$ & $81.8 \pm 19$ & $79.8 \pm 22.9$ & $0.8005^{b}$ \\
\hline 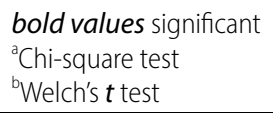 & & & \\
\hline
\end{tabular}

Table 4 Differences in clinical and functional outcome between conservative and operative group

\begin{tabular}{|c|c|c|c|}
\hline & Conservative & Operative & $p$ \\
\hline Primary treatment & 10 & 21 & - \\
\hline \multicolumn{4}{|l|}{ Nonunion } \\
\hline Hypertrophic & 3 & 2 & $0.1473^{\mathrm{a}}$ \\
\hline Atrophic & 7 & 19 & $0.1473^{\mathrm{a}}$ \\
\hline \multicolumn{4}{|l|}{ Revision surgery } \\
\hline Time until revision (months) & $14.8 \pm 8.2$ & $22.4 \pm 22.8$ & $0.1865^{\mathrm{b}}$ \\
\hline Operations until revision & 0 & $1.4 \pm 0.6$ & $0.0001^{b}$ \\
\hline Operation time (min) & $91.2 \pm 36.2$ & $98.8 \pm 34.6$ & $0.5866^{b}$ \\
\hline \multicolumn{4}{|l|}{ Clinical outcome } \\
\hline Age-adjusted Constant score of the injured side & $91.5 \pm 16.6$ & $93.1 \pm 17.2$ & $0.8069^{b}$ \\
\hline \multicolumn{4}{|l|}{ Radiological outcome } \\
\hline Bony union & 10 & 20 & $0.483^{\mathrm{a}}$ \\
\hline \multicolumn{4}{|l|}{ Complications } \\
\hline Re-operation because of wound complication & 1 & 1 & $0.99^{\mathrm{b}}$ \\
\hline Total operations & $1.7 \pm 0.46$ & $2.95 \pm 0.46$ & $0.0001^{b}$ \\
\hline Clavicular paresthesia & 5 & 15 & $0.2438^{\mathrm{a}}$ \\
\hline 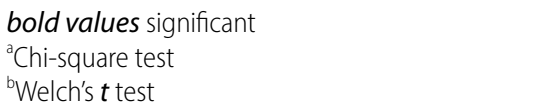 & & & \\
\hline
\end{tabular}

the revision surgery and were able to return to work and sport. Radiographic union was reached in 30 out of 31 patients and the overall complication rate was low.

Longer-term follow up data on the functional outcome after surgical treatment of clavicular nonunions in large cohorts are rarely reported. We identified a total of 15 studies over the past 25 years that included the assessment of functional results through either the Constant or DASH score (- Table 5).

In summary, the majority of the available studies are retrospective analyses with limited cohort sizes. Rollo et al. presented a larger study population with
57 consecutive cases [26]. Although we were not able to significantly increase the cohort size compared with the available literature, we report the results of two different study centers. Interestingly, our cohort is older on average than any of the aforementioned studies $(52.3 \pm 15.2$ years $)$. The clinical followup and the rate between atrophic and hypertrophic nonunions are comparable to those in the literature. Furthermore, similar to the available functional outcome assessment data, the Constant score is significantly decreased compared with the noninjured side (95.6 vs. 82.2). The difference is greater than the accepted threshold for the minimal clinically important difference for the Constant score [17]. Additionally, the range of motion for abduction was decreased in our study. Nevertheless, bony union was achieved in $96.8 \%$ of the cases and only two complications requiring revision surgery were recorded.

Additionally, our study provides detailed information on the technical aspects of the surgical revision. Huang et al. reported a mean operation time of $96 \mathrm{~min}$, which is comparable to our data and longer than the average operation time for the initial fixation of a clavicular fracture in our cohort $(96.3 \pm 35.9$ vs. $53.3 \pm 15.8 \mathrm{~min} ; p=0.0002$; [11]). Also, the plate length seems to be longer in the revision case compared with the initial surgery $(8.1 \pm 1.2$ vs. $8.7 \pm 1.4)$.

The comparison between initially nonoperative and operative treatment revealed no difference in the outcome measures. Interestingly, significantly more smokers were seen in the conservative cohort. This is in line with studies that identified smoking as an independent risk factor for the development of a nonunion [12].

The case presented in 0 Fig. 1 is a good example of a typical failure of primary clavicular fracture fixation and secondary development of complications like infection and nonunion. In these cases, in which stability of the fixation seems to be the major issue, double plating is a good option to increase the overall fixation stability $[15,22]$.

\section{Limitations}

There are several inherent limitations to our study. Firstly, this is a retrospective cohort analysis solely reporting functional and radiographic outcomes. Like other comparable studies published previously, we were not able to recruit a larger cohort, although we did manage (for the first time) to report results from two centers. In addition, the indication for the index therapy (conservative vs. operative) remained unclear and was based on the decision of the treating surgeon. Similarly, the surgeon decided on the need for a bone graft in the revision situation. Therefore, the revision procedures were not standardized. 


\begin{tabular}{|c|c|c|c|c|c|c|c|c|c|}
\hline Author & Year & $n$ & $\begin{array}{l}\text { Mean age } \\
\text { (years) }\end{array}$ & $\begin{array}{l}\text { Follow-up } \\
\text { (months) }\end{array}$ & $\begin{array}{l}\text { Atrophic vs. } \\
\text { hypertrophic }\end{array}$ & $\begin{array}{l}\text { Constant } \\
\text { score }\end{array}$ & $\begin{array}{l}\text { DASH } \\
\text { score }\end{array}$ & $\begin{array}{l}\text { Union rate } \\
(\%)\end{array}$ & $\begin{array}{l}\text { Compli- } \\
\text { cation }\end{array}$ \\
\hline Olsen et al. [25] & 1995 & 15 & 34 & 24.8 & 9 vs. 6 & 87.9 & NA & 94 & None \\
\hline Bradbury et al. [3] & 1996 & 32 & NA & 72 & 21 vs. 10 & 85 & NA & 97 & 1 \\
\hline Wentz et al. [31] & 1999 & 22 & $18-33$ & NA & 19 vs. 3 & 97 & NA & 100 & None \\
\hline Kabak et al. [13] & 2004 & 33 & $39.3 / 43.6$ & 44.2 & NA & NA & $14.8 / 6.7$ & $100 / 87.5$ & 6 \\
\hline O'Conner [24] & 2004 & 24 & 38 & 42.1 & 14 vs. 10 & NA & a & 92 & 2 \\
\hline Endrizzi et al. [7] & 2008 & 45 & 38.7 & NA & NA & NA & 14.6 & 93 & 3 \\
\hline Khan et al. [16] & 2008 & 11 & NA & 36 & 4 vs. 5 & NA & 24 & 100 & 2 \\
\hline Huang et al. [11] & 2009 & 21 & 32 & 65.7 & 17 vs. 4 & 91 & NA & 100 & 1 \\
\hline Baker et al. [1] & 2010 & 15 & 39 & 12 & NA & NA & 14.5 & 100 & None \\
\hline Stufkens et al. [30] & 2010 & 21 & 48.2 & 30 & NA & NA & 22.8 & 100 & 2 \\
\hline Faraud et al. [8] & 2014 & 21 & 47 & 41 & 16 vs. 5 & 84 & 17 & 90 & 6 \\
\hline Beirer et al. [2] & 2017 & 11 & 44 & 27 & NA & 82 & NA & 100 & 1 \\
\hline Rollo et al. [26] & 2017 & 57 & 35 & 42 & 35 vs. 22 & NA & 16.7 & 98 & 1 \\
\hline Chen W. et al. [4] & 2018 & 17 & 44 & 38.5 & 8 vs. 9 & 75.5 & 19.9 & 100 & None \\
\hline Marsalli et al. [19] & 2019 & 14 & 44.9 & 77 & NA & 87.5 & NA & 86 & 2 \\
\hline
\end{tabular}

\section{Practical conclusion}

- Operative treatment for clavicular nonunion with iliac bone grafting and plate fixation is a well-established and safe procedure.

- Radiographic union and good functional outcomes can regularly be achieved.

- Our study showed that this also applies to an older patient cohort.

- In order to compare outcome measures between initial conservative and operative treatment, significantly larger cohorts are needed.

\section{Corresponding address}

Dr. med. Philipp A. Michel,
M.Sc.
Department of Trauma, Hand
and Reconstructive Surgery,
University Hospital Münster
Waldeyer Str. 1, 48149 Mün-
ster, Germany
Philipp.Michel@
ukmuenster.de

Funding. Open Access funding provided by Projekt DEAL.

\section{Compliance with ethical guidelines}

Conflict of interest. P.A. Michel, B. Schliemann, M.J. Raschke, J.C. Katthagen, L.F. Heilmann, F. Dyrna, F. Sax, M. Warnhoff, H. Lill and R.-O. Dey Hazra declare that they have no competing interests.

All procedures performed in studies involving human participants or on human tissue were in accordance with the ethical standards of the responsible committee on human experimentation (institutional and national) and with the Helsinki Declaration of 1975 (in its most recently amended version). The ethics committee of the Westfaelische Wilhelms University (2019159-f-S) as well as the ethics committee of the medical school of Hannover (8688_BO_S_2019) approved the study. Informed consent was obtained from all individual participants included in the study.

Open Access. This article is licensed under a Creative Commons Attribution 4.0 International License, which permits use, sharing, adaptation, distribution and reproduction in any medium or format, as long as you give appropriate credit to the original author(s) and the source, provide a link to the Creative Commons licence, and indicate if changes were made. The images or other third party material in this article are included in the article's Creative Commons licence, unless indicated otherwise in a credit line to the material. If material is not included in the article's Creative Commons licence and your intended use is not permitted by statutory regulation or exceeds the permitted use, you will need to obtain permission directly from the copyright holder. To view a copy of this licence, visit http://creativecommons.org/licenses/by/4.0/.

\section{References}

1. Baker JF, Mullet H (2010) Clavicle non-union: autologous bone graft is not a necessary augment to internal fixation. Acta Orthop Belg 76(6):725-729

2. Beirer M, Banke IJ, HarrasserN Netal (2017) Mid-term outcome following revision surgery of clavicular non- and malunion using anatomic locking compression plate and iliac crest bone graft. BMC Musculoskelet Disord 18:129

3. Bradbury N, Hutchinson J, Hahn D et al (1996) Clavicular nonunion. 31/32 healed after plate fixation and bone grafting. Acta Orthop Scand 67:367-370

4. Chen W, Tang K, Tao X et al (2018) Clavicular non-union treated with fixation using locking compression plate without bone graft. J Orthop Surg Res 13:317

5. Court-Brown CM, Caesar B (2006) Epidemiology of adult fractures: a review. Injury 37:691-697

6. Ebraheim NA, Mekhail AO, Darwich M (1997) Open reduction and internal fixation with bone grafting of clavicular nonunion. JTrauma 42:701-704

7. Endrizzi DP, White RR, Babikian GM et al (2008) Nonunion of the clavicle treated with plate fixation: a review of forty-seven consecutive cases. JShoulder Elbow Surg 17:951-953

8. Faraud A, Bonnevialle N, Allavena C et al (2014) Outcomes from surgical treatment of middle-third clavicle fractures non-union in adults: a series of 21 cases. Orthop Traumatol Surg Res 100:171-176

9. Guerra E, Previtali D, Tamborini S et al (2019) Midshaft clavicle fractures: surgery provides better results as compared with nonoperative treatment: a meta-analysis. Am J Sports Med 47:3541-3551

10. Herteleer M, Hoekstra H, Nijs S (2018) Diagnosis and treatment of clavicular fractures in Belgium between 2006 and 2015. J Shoulder Elbow Surg 27:1512-1518

11. Huang TL, Lin FH, Hsu HC (2009) Surgical treatment for non-union of the mid-shaft clavicle using 
a reconstruction plate: scapular malposition is related to poor results. Injury 40:231-235

12. Jarvis NE, Halliday L, Sinnott M et al (2018) Surgery for the fractured clavicle: factors predicting nonunion. JShoulder Elbow Surg 27:e155-e159

13. KabakS, Halici M, Tuncel Metal (2004) Treatment of midclavicular nonunion: comparison of dynamic compression plating and low-contact dynamic compression plating techniques. JShoulder Elbow Surg 13:396-403

14. Katolik LI, Romeo AA, Cole BJ et al (2005) Normalization of the constant score. J Shoulder Elbow Surg 14:279-285

15. Katthagen JC, Schliemann B, Michel PA et al (2019) Clinical application and outcomes of upper extremity double plating. ZOrthop Unfall. https:// doi.org/10.1055/a-0862-1070

16. Khan SA, Shamshery P, Gupta V et al (2008) Locking compression plate in long standing clavicular nonunions with poor bone stock. J Trauma 64:439-441

17. Kukkonen J, Kauko T, Vahlberg T et al (2013) Investigating minimal clinically important difference for constant score in patients undergoing rotator cuff surgery. J Shoulder Elbow Surg 22:1650-1655

18. Lenza M, Buchbinder R, Johnston RV et al (2019) Surgical versus conservative interventions for treating fractures of the middle third of the clavicle. Cochrane Database Syst Rev 1:CD9363

19. Marsalli M, Rojas JT, Barahona M (2019) Acute surgery vs. non-union surgery of displaced midshaft clavicle fractures: a case-control study. Cureus 11:e5480

20. Martetschlager F, Gaskill TR, Millett PJ (2013) Management of clavicle nonunion and malunion. JShoulder Elbow Surg 22:862-868

21. Mcknight B, Heckmann N, Hill JR et al (2016) Surgical management of midshaft clavicle nonunions is associated with a higher rate of short-term complications compared with acute fractures. JShoulder Elbow Surg 25:1412-1417

22. Michel PA, Katthagen JC, Heilmann LF et al (2019) Biomechanics of upper extremity double plating. Z Orthop Unfall. https://doi.org/10.1055/a-08626334

23. Nordqvist A, Petersson C (1994) The incidence of fractures of the clavicle. Clin Orthop Relat Res 300:127-132

24. O'Connor D, Kutty S, McCabe JP (2004) Long-term functional outcome assessment of plate fixation and autogenous bone grafting for clavicular nonunion. Injury 35:575-579

25. Olsen BS, Vaesel MT, Sojbjerg JO (1995) Treatment of midshaft clavicular nonunion with plate fixation and autologous bone grafting. J Shoulder Elbow Surg 4:337-344

26. Rollo G, Vicenti G, Rotini R et al (2017) Clavicle aseptic nonunion: is there a place for cortical allogenic strut graft? Injury 48:S60-S65

27. Schneider P, Bransford R, Harvey E et al (2019) Operative treatment of displaced midshaft clavicle fractures: has randomised control trial evidence changed practice patterns? BMJ Open 9:e31118

28. Schnetzke M, Morbitzer C, Aytac S et al (2015) Additional bone graft accelerates healing of clavicle non-unions and improves long-term results after 8.9 years: a retrospective study. JOrthop Surg Res 10:2

29. Smeeing DPJ, van der Ven DJC, Hietbrink F et al (2017) Surgical versus nonsurgical treatment for midshaft clavicle fracturesin patients aged 16 years and older: a systematic review, meta-analysis, and comparison of randomized controlled trials and observational studies. Am J Sports Med 45:1937-1945

30. Stufkens SA, Kloen P (2010) Treatment of midshaft clavicular delayed and non-unions with anteroinferior locking compression plating. Arch Orthop Trauma Surg 130:159-164

31. Wentz S, Eberhardt C, Leonhard T (1999) Reconstruction plate fixation with bone graft for midshaft clavicular non-union in semi-professional athletes. JOrthop Sci 4:269-272

32. Woltz S, Stegeman SA, Krijnen P et al (2017) Plate fixation compared with nonoperative treatment for displaced midshaft clavicular fractures: a multicenter randomized controlled trial. J Bone Joint Surg Am 99:106-112

33. Zlowodzki M, Zelle BA, Cole PA et al (2005) Treatment of acute midshaft clavicle fractures: systematic review of 2144 fractures: on behalf of the evidence-based orthopaedic trauma working group. JOrthop Trauma 19:504-507

\section{Dank an die Gutachter}

Allen Experten und Expertinnen, die im Jahr 2019 Manuskripte für die Obere Extremität begutachtet haben, danken wir sehr herzlich für ihre konstruktive und gewissenhafte Arbeit. Durch ihre Expertise und ihr Engagement im Rahmen des Peer-ReviewVerfahrens tragen sie ganz wesentlich dazu bei, die hohe Qualität der Zeitschrift zu sichern.

PD Dr. Knut Beitzel, München Prof. Dr. Sepp Braun, Innsbruck Prof. Dr. Ulrich-H. Brunner, Hausham PD Dr. Klaus Burkhart, Pforzheim Dr. Alexander Ellwein, Hannover Dr. Christian Gerhardt, Karlsruhe Prof. Dr. Thorsten Gühring, Pforzheim Dr. Michael Hackl, Köln

Prof. Dr. Pierre Hepp, Leipzig

Prof. Dr. Philip Kasten, Tübingen PD Dr. Christoph Katthagen, Münster Dr. Rolf Michael Krifter, Salzburg Prof. Dr. Lars Lehmann, Karlsruhe Dr. Petra Magosch, Heidelberg PD Dr. Frank Martetschläger, München PD Dr. Frieder Mauch, Stuttgart PD Dr. Philipp Moroder, Berlin Prof. Dr. Andreas Niemeier, Hamburg PD Dr. Ben Ockert, München PD Dr. Thilo Patzer, Düsseldorf Prof. Dr. Patric Raiss, München PD Dr. Marc Schnetzke, Ludwigshafen Prof. Dr. Dominik Seybold, Düsseldorf PD Dr. Sebastian Siebenlist, München Prof. Dr. Mark Tauber, München Dr. Markus Wambacher, Innsbruck PD Dr. Kilian Wegmann, Köln Prof. Dr. Mathias Wellmann, Hannover PD Dr. Andreas Werner, Hamburg 